\title{
Idarubicin-Eluting Beads
}

National Cancer Institute

\section{Source}

National Cancer Institute. Idarubicin-Eluting Beads. NCI Thesaurus. Code $C 90593$.

A sustained-release drug delivery embolization system containing small polymeric beads impregnated with the anthracycline antibiotic idarubicin with potential antineoplastic activity. The beads consist of polyvinyl alcohol (PVA) microspheres modified with sulfonic acid groups and loaded with idarubicin. During transarterial chemoembolization (TACE) in the hepatic artery, idarubicin-eluting beads embolize to the tumor vasculature, occlude tumor blood vessels and induce ischemic necrosis of tumor tissue due to mechanical blockage of the tumor vasculature. Simultaneously, idarubicin-eluting beads release cytotoxic idarubicin locally and in a sustained manner. This may result in idarubicinmediated inhibition of tumor cell proliferation. 